\title{
Necrotizing nocardial scleritis after combined penetrating keratoplasty and phacoemulsification with intraocular lens implantation: a case report and review of the literature
}

\author{
Esclerite necrosante por Nocardia após cera toplastia penetrante e facoemulsificação \\ com implante de lente intra-ocular: caso clínico e revisão de literatura
}

\author{
Jerome Charles Ramos-Esteban ${ }^{1}$ \\ Juan Javier Servat ${ }^{2}$ \\ Renata Siqueira da Silva ${ }^{3}$ \\ Renato Ambrósio Jr. ${ }^{4}$ \\ Shachar Tauber ${ }^{5}$ \\ Frank Bia ${ }^{6}$
}

\begin{tabular}{l} 
ABSTRACT \\
\hline We report the history and clinical presentation of an 88-year-old female \\
with Fuchs dystrophy who developed an acute anterior necrotizing \\
scleritis in her left eye 23 months after an uncomplicated combined \\
penetrating keratoplasty and phacoemulsification with intraocular lens \\
implantation which progressed to slceral perforation with uveal prolapses. \\
The patient underwent a complete systemic work-up for both autoimmune \\
and infectious causes of scleritis. Surgical specimens of the area of scleral \\
perforation were sent for histology and microbiologic studies. Analysis of \\
surgical specimens revealed the presence of culture-proven Nocardia \\
asteroides as a causative agent for the patient's scleral perforation. \\
Results of her systemic autoimmune work-up were not conclusive. Suc- \\
cessful treatment with tectonic scleral reinforcement with donor corneal \\
tissue and preserved pericardium, oral and topical trimethoprim-sulfame- \\
thoxazole and topical amikacin salvaged the globe and increased vision. \\
The patient's final best-corrected visual acuity sixteen months after her \\
lastoperation remains 20/70. Prompt surgical intervention with submission \\
of appropriate specimens for pathological diagnosis and microbiology, \\
along with consultation with rheumatologic and infectious disease \\
specialists, are mandatory to minimize visual loss in cases of suspected \\
infectious necrotizing scleritis.
\end{tabular}

Keywords: Scleritis; Nocardia asteroides; Eye infections; Keratoplasty, penetrating; Phacoemulsification; Case reports [Publication type]

\section{INTRODUCTION}

Nocardia asteroides is a rare bacterial cause of chronic infectious scleritis; one which is difficult to diagnose and which can lead to potential sight-threatening complications. Predisposing factors include cataract surgery $^{(1-2)}$, scleral buckle surgery ${ }^{(3)}$, trauma with vegetable matter ${ }^{(4)}$ and soft contact lens-related keratitis with extension to the sclera ${ }^{(5)}$. We report the first case of Nocardia-associated infectious scleritis leading to perforation in a patient who had undergone prior penetrating keratoplasty, cataract extraction and intraocular lens implantation.

\section{CASE REPORT}

An 88-year-old woman underwent simultaneous penetrating kerato- 
356 Necrotizing nocardial scleritis after combined penetrating keratoplasty and phacoemulsification with intraocular lens implantation: a case report and review of the literature

plasty and phacoemulsification with posterior chamber intraocular lens implantation in the left eye (LE) for cataract and bullous keratopathy secondary to Fuchs endothelial dystrophy in November, 2001.

The patient had an uncomplicated postoperative course for fourteen months achieving BCVA (best corrected visual acuity) LE of 20/30. Fourteen months after her triple procedure she developed a corneal ulcer located in the inferotemporal quadrant of the corneal graft related to suture abscess. Corneal scrapings revealed Pseudomonas aeruginosa, successfully treated with topical ciprofloxacin $0.3 \%$, tobramicyn, prednisolone acetate $1 \%$, and oral ciprofloxacin $500 \mathrm{mg}$ twice a day. All suspicious corneal sutures were subsequently removed without complication. The corneal ulcer healed uneventfully leaving a small peripheral stromal opacity in the corneal graft.

Twenty-one months postoperatively the patient complained of severe LE pain and redness. BCVA LE was 20/40; a new peripheral epithelial defect overlying the old stromal opacity was noted on examination (Figure 1). Despite treatment which included bandage contact lens, aggressive lubrication and topical $1 \%$ prednisolone acetate, the persistent epithelial defect progressed to $40 \%$ thinning of peripheral cornea. At this time the presence of an area of acute necrotizing nodular scleritis was noted and promptly cultured. Gram stain and cultures were negative. Topical treatment consisted of ciprofloxacin, fortified vancomycin and oral ciprofloxacin $500 \mathrm{mg}$.

An autoimmune necrotizing nodular scleritis was suspected. The patient was started on oral prednisone $40 \mathrm{mg}$ once daily. She underwent a systemic evaluation. There was a positive rheumatoid factor at 1:40 (reference value $<1: 20$ ). CT scan of abdomen and pelvis with oral and IV contrast revealed the presence of multiple bilateral wedge-shaped renal perfusion defects and multiple small peripheral areas of splenic infarcts consistent with vasculitis.

At twenty-two months, BCVA LE was 20/70, and the patient complained of light sensitivity, increased pain and redness in her LE. Examination revealed a severely hyperemic conjunctiva in the inferotemporal quadrant, associated with a mucoid yellowish white discharge (Figure 2). The epithelial defect size remained unchanged. Topical fortified vancomycin and oral ciprofloxacin were discontinued after repeat culture showed coagulase-negative Staphylococcus aureus. Topical moxifloxacin $0.5 \%$, ciprofloxacin, prednisolone acetate $1 \%$ four times a day and oral prednisone, $80 \mathrm{mg}$ once daily, were instituted.

At 23 months postoperatively, the patient's BCVA LE was count fingers. The area of nodular scleral thinning in the temporal quadrant had perforated, with uveal prolapse. The corneal graft remained clear centrally, but a mild anterior chamber reaction was seen. The scleral perforation was repaired with donor cornea tissue, and lamellar reinforcement with preserved pericardium was performed in the adjacent severely thinned region of the sclera (Figure 3).

The patient was started on oral gatifloxacin, $400 \mathrm{mg}$ once a

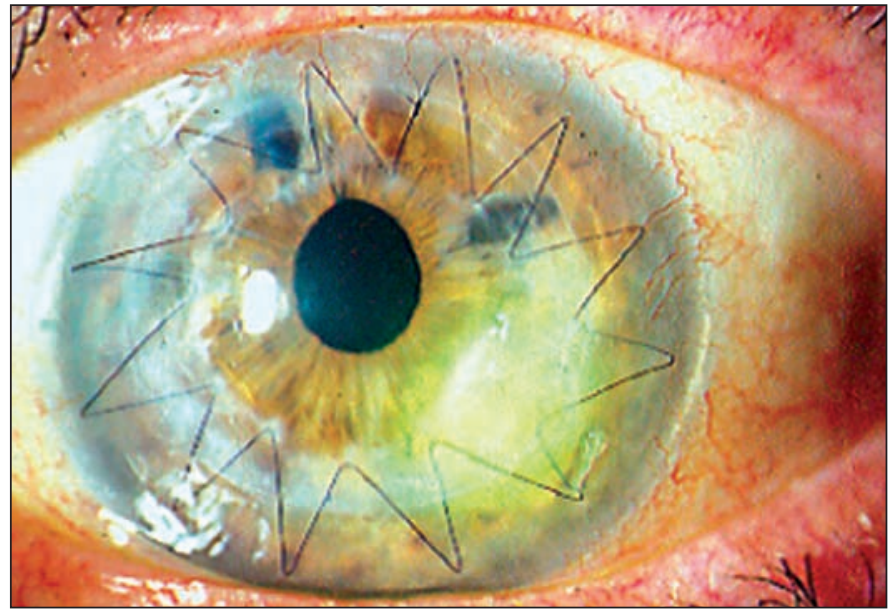

Figure 1 - Epithelial defect 14 months after penetrating keratoplasty and cataract surgery left eye

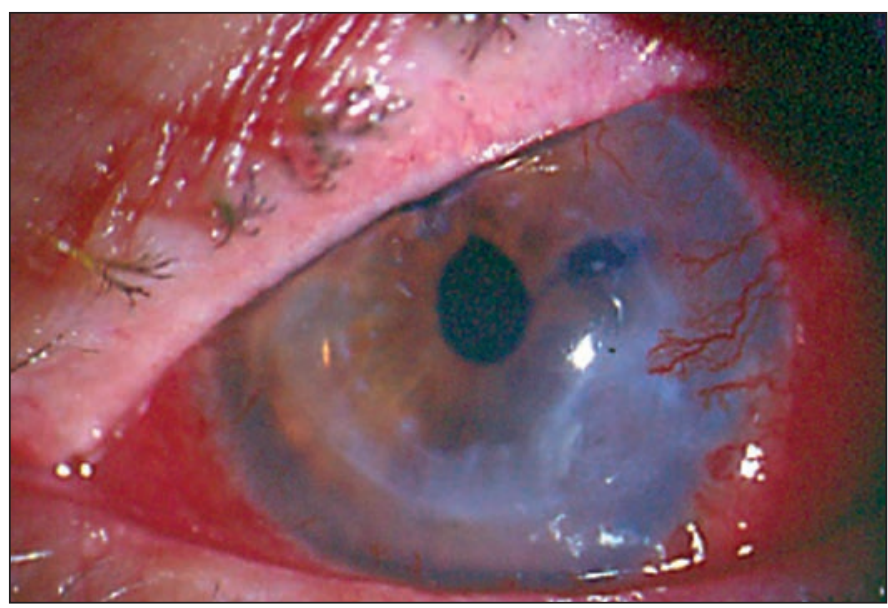

Figure 2 - Acute anterior necrotizing scleritis, with impending scleral perforation in the temporal quadrant of the left eye 21 months after penetrating keratoplasty

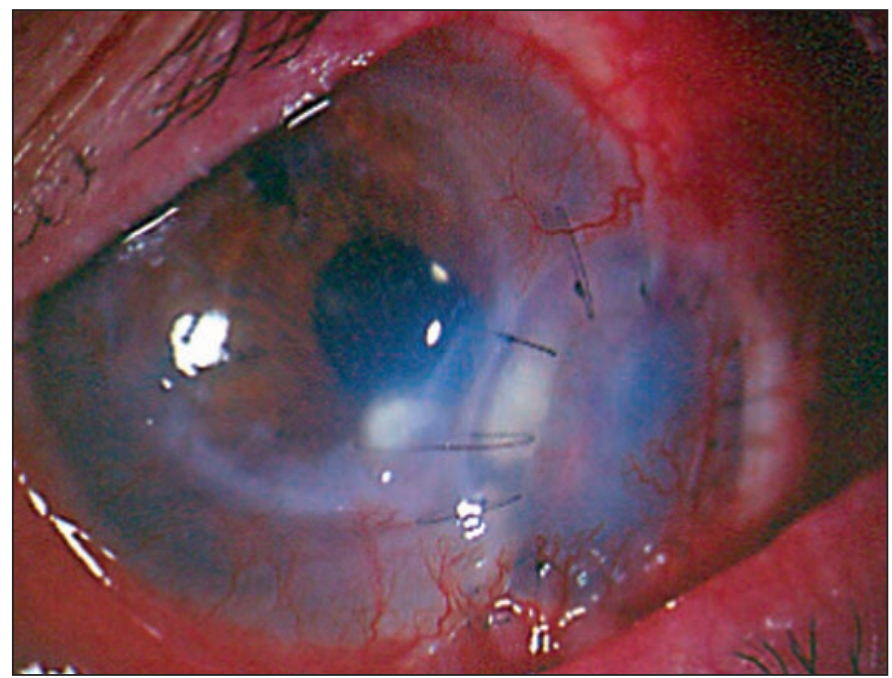

Figure 3 - Immediate postoperative scleral perforation was repaired with donor cornea and lamellar reinforcement with preserved pericardium 
day, and continued on topical moxifloxacin, ciprofloxacin, $1 \%$ prednisolone acetate drops, and prednisone $80 \mathrm{mg}$ once a day. Surgical pathology of the left scleral button showed severe acute and chronic inflammation with palisading giant cells, compatible with a granulomatous nodular scleritis. The iris/ciliary body specimens revealed acute and chronic inflammation consistent with extension of nodular scleritis. The scleral button and iris/ciliary body revealed the presence of branching Grampositive rods. Acid-fast and fungal stains were negative.

Topical trimethropim-sulfamethoxazole and amikacin drops every two hours to the LE, and oral trimethoprim $(160 \mathrm{mg})$ sulfamethoxazole $(800 \mathrm{mg}$ ) were begun twice a day. Gatifloxacin was discontinued and prednisone was tapered to $10 \mathrm{mg}$ once a day over a period of 10 days. Surgical specimens of both scleral and uveal tissue revealed Nocardia asteroides on blood agar (Figure 4).

Within one month of initiation of treatment for Nocardia, the patient was noted to have less pain and vision improved to $20 / 200$. The original graft remained clear and compact centrally. At her last follow-up visit, sixteen months after her second corneal graft (Figure 5), the patient's final BCVA was 20/70.

\section{DISCUSSION}

Nocardia asteroides is an aerobic, Gram-positive, thin, immotile, branching filamentous bacteria belonging to the Actinomycetaceae family ${ }^{(6)}$. Nocardia were first recognized in 1889 , is usually found in soil, mud, dust and decaying vegetation. Nocardia asteroides usually does not cause an acute fulminant type of infection. However, in the presence of immunosuppressive therapy including chemotherapy ${ }^{(7-8)}$, topical $^{(2-3,9)}$ or systemic corticosteroids ${ }^{(10)}$, the clinical presentations of nocardial ocular infections can be devastating, and even progress to central nervous system involvement.

Cases of nocardial keratitis after myopic keratomileusis ${ }^{(11)}$ and laser in situ keratomileusis (LASIK) retreatment for residual myopia ${ }^{(12)}$ have recently been reported. Inflammatory necrotizing scleritis represents a sight-threatening condition that can potentially lead to scleral thinning and perforation of the eye. The differential diagnosis of necrotizing scleritis includes systemic inflammatory diseases such as rheumatoid arthritis and Wegener's granulomatosis and metabolic disorders such as gout and thyrotoxicosis. It also includes various skin diseases such as erythema nodosum, acne rosacea and infectious diseases such as tuberculosis, syphilis, herpes simplex, herpes zoster, Acanthamoeba species, pseudomonas and nocardial infections ${ }^{(13)}$.

Six cases of Nocardia asteroides-associated necrotizing scleritis have been reported ${ }^{(1,9)}$. Risk factors for the development of Nocardia scleritis include cataract surgery ${ }^{(1-2)}$, scleral buckle $^{(3)}$, trauma with vegetable matter ${ }^{(4)}$, and soft contact lens related keratitis with extension to the sclera ${ }^{(6)}$. One case of spontaneous Nocardia scleritis in a poorly controlled diabe-

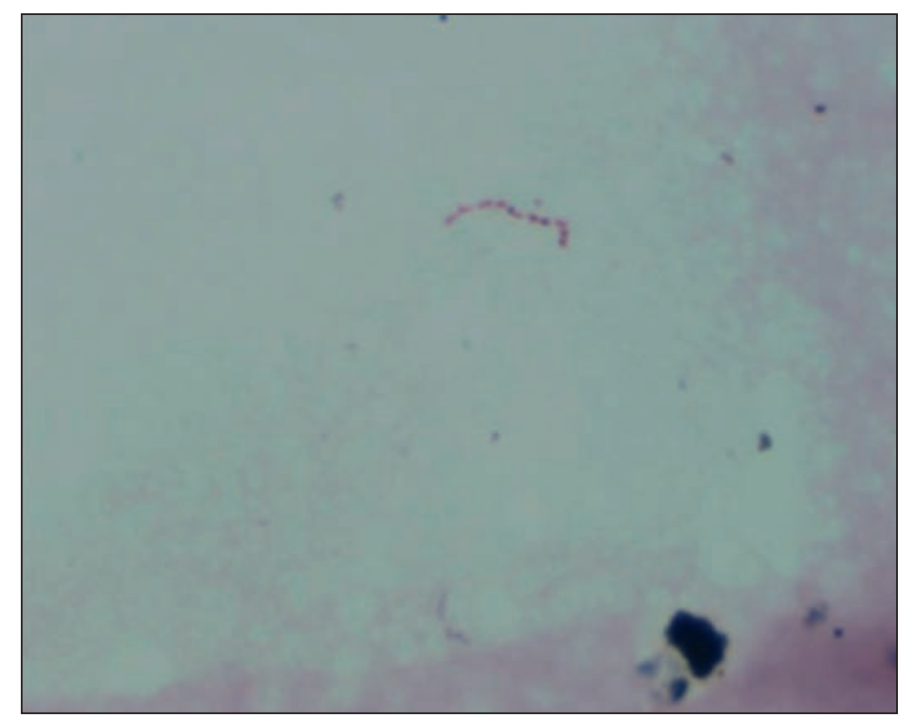

Figure 4 - Nocardia asteroides. Gram-positive branching filamentous bacteria.

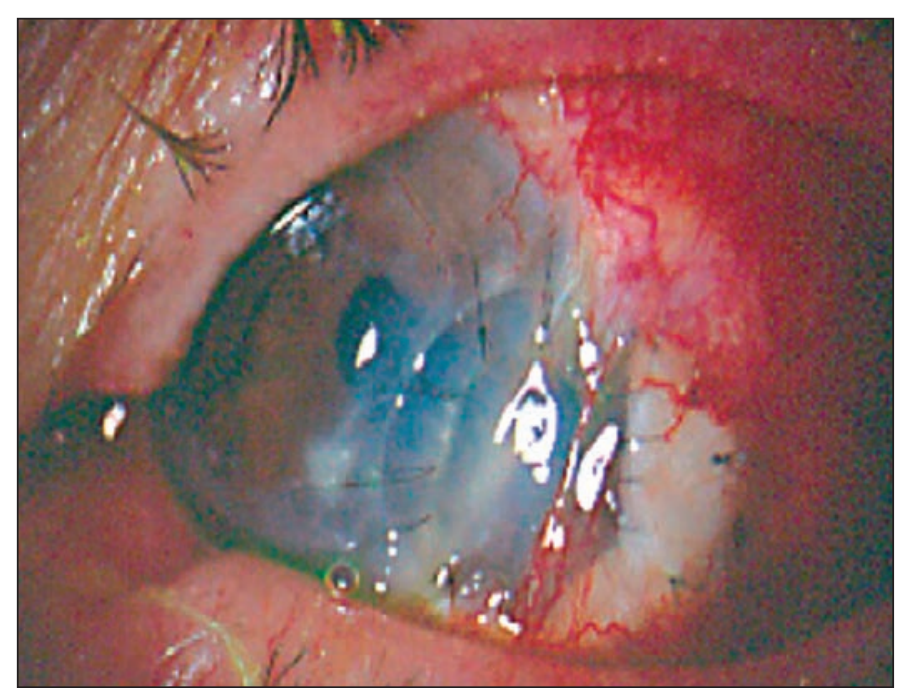

Figure 5 - Ten months after second corneal graft, central corneal graft remains clear and second graft became opacified

tic male patient without history of trauma or intraocular surgery has been reported ${ }^{(9)}$. Another case of spontaneous Nocardia scleritis has been reported in a patient without risk factors after a week with a history of manipulation of the soil ${ }^{(14)}$.

Infectious scleritis results from an extension of keratitis involving the limbus into adjacent sclera. Pain and discharge are the usual symptoms. Conjunctival and scleral inflammation with areas of necrosis, thinning, hemorrhage and areas of circumscribed scleral abscesses with purulent discharge are typical ${ }^{(6)}$.

Our case is unique because no previous cases of Nocardia asteroides scleritis have been reported following combined penetrating keratoplasty and phacoemulsification with intraocular lens implantation. Isolated Nocardia asteroides 
358 Necrotizing nocardial scleritis after combined penetrating keratoplasty and phacoemulsification with intraocular lens implantation: a case report and review of the literature

corneal ulcer after penetrating keratoplasty has been reported, in the past. The difference between our patient and the patient reported by Colamina relies on the scleral involvement seen in our patient ${ }^{(15)}$.

Multiple confounding factors, including the presence of a positive rheumatoid factor, and the poor patient's response to prior antibiotic therapy led us to suspect an autoimmune etiology for her scleritis. In a previous report by Knox et al.$^{(4)}$ the presence of positive antinuclear and perinuclear anti-neutrophilic antibodies were reported in a case of nocardial scleritis 10 years after scleral buckle surgery.

Some authors reported a case of necrotizing nodular scleritis secondary to Nocardia in a 54-year-old male, without a history of trauma or ocular surgery ${ }^{(9)}$. In our patient, scleral thinning progressed despite changing treatment to once a day oral gatifloxacin $400 \mathrm{mg}$, prednisone $80 \mathrm{mg}$ with topical moxifloxacin, ciprofloxacin and prednisolone acetate hourly. Emergent repair of scleral perforation required a second donor cornea and inferior scleral reinforcement with preserved pericardium to preserve the integrity of the globe.

A similar case was reported despite correct aggressive antibiotic therapy for nocardial infection with both intravenous and hourly topical trimethoprim-sulfamethoxazole, infection led to enucleation to limit the extent of associated disease ${ }^{(1)}$.

Our choice of antibiotics was based on the superior in vitro efficacy of trimethoprim/sulfamethoxazole for nocardial infections over that of either trimethoprim or sulfacetamide sodium alone, as demonstrated in a case of a 90-year-old woman who developed necrotizing nocardial scleritis seven days after extracapsular cataract surgery ${ }^{(2,16)}$.

A case of an 83-year-old male was reported with history of bilateral scleral buckle procedure 10 years prior to development of Nocardia scleritis. This was treated with topical amikacin and sulfacetamide drops, subconjunctival amikacin injection and systemic trimethoprim-sulfamethoxazole ${ }^{(4)}$. The patient's sclera healed, leaving an area of scleral thinning and sterile corneal infiltrate which was thought to be a result of amikacin toxicity. Another reported a case of Nocardia scleritis in a 58-year-old farmer who was previously treated with topical betamethasone and experienced traumatic injury to the LE that involved vegetable matter. Microbiologic studies revealed Nocardia asteroides sensitive only to cefazolin. The patient was successfully treated with intravenous cefazolin ${ }^{(3)}$.

The last case illustrates the variable antibiotic sensitivity of Nocardia asteroides to trimethoprim-sulfamethoxazole ${ }^{(3)}$. Amikacin and minocycline have been recommended in cases of nocardial infection resistant to trimethoprim/sulfamethoxazole ${ }^{(17)}$.

In cases of necrotizing scleritis with an unclear autoimmune etiology and poor response to both topical corticosteroids and standard antibiotics it is important to perform a biopsy of the nodule and send it for microbiological and histopathological analysis. Early recognition of nocardial infections can prevent the development of scleral perforation. Furthermore, good communication between the ophthalmologist, the clini- cal microbiology laboratory and the infectious disease team is essential for the early diagnosis and treatment of Nocardiaassociated scleritis.

\section{RESUMO}

Relato de caso de esclerite necrosante aguda, evoluindo para perfuração escleral com prolapso uveal, 23 meses após procedimento de ceratoplastia penetrante e facoemulsificação com implante de lente intra-ocular no olho esquerdo sem intercorrências. A paciente foi submetida à avaliação completa autoimune para esclerite. Biópsia da área de perfuração escleral foi encaminhada para avaliação patológica e microbiológica. Análise de material cirúrgico revelou presença de cultura proveniente de Nocardia asteroides como agente causal da perfuração escleral. Resultados de exames do sistema auto-imune não foram conclusivos. Tratamento foi um sucesso com reforço escleral tectônico do tecido corneano doador, utilização de pericárdio preservado, associado ao uso sistêmico e tópico de sulfametoxazol-trimetropina e amicacina colírio. Apresentou melhora visual após o tratamento e a melhor correção visual final, 16 meses após o último procedimento cirúrgico foi de 20/70. Intervenção cirúrgica precoce, análise patológica e microbiológica do material, associados a consulta a especialistas na área de doenças infecciosas e reumatologia, são primordiais para minimizar perda visual em casos de suspeitas de esclerite infecciosa necrosante.

Descritores: Esclerite; Nocardia asteroides; Infecções oculares; Ceratoplastia penetrante; Facoemulsificação; Relatos de casos [Tipo de publicação]

\section{REFERENCES}

1. Kattan HM, Pflugfelder SC. Nocardia scleritis. Am J Ophthalmol. 1990; 110(4):446-7.

2. Brooks JG, Jr., Mills RA, Coster DJ. Nocardial scleritis. Am J Ophthalmol. 1992;114(3):371-2.

3. Basti S, Gopinathan U, Gupta S. Nocardial necrotizing scleritis after trauma. Successful outcome using cefazolin. Cornea. 1994;13(3):274-6.

4. Knox CM, Whitcher JP, Cevellos V, Margolis TP, Irvine AR. Nocardia scleritis. Am J Ophthalmol. 1997;123(5):713-4.

5. Sridhar MS, Cohen EJ, Rapuano CJ, Lister MA, Laibson PR. Nocardia asteroides sclerokeratitis in a contact lens wearer. CLAO J. 2002;28(2):66-8.

6. Sridhar MS, Gopinathan U, Garg P, Sharma S, Rao GN. Ocular nocardia infections with special emphasis on the cornea. Surv Ophthalmol. 2001;45(5): 361-78.

7. Lerner PI. Pneumonia due to actinomyces, arachnia and nocardia. In: Pennington JE, Respiratory infections: diagnosis and management. New York: Raven Press; 1983. p.387-96.

8. Lissner GS, O'Grady R, Choromokos E. Endogenous intraocular Nocardia asteroides in Hodgkin's disease. Am J Ophthalmol. 1978;86(3):388-94.

9. Choudhry S, Rao SK, Biswas J, Madhavan HN. Necrotizing nocardial scleritis with intraocular extension: a case report. Cornea. 2000;19(2):246-8.

10. Penikett EJ, Rees DL. Nocardia asteroides infection of the nasal lacrimal system. Am J Ophthalmol. 1962;53:1006-8.

11. Nascimento EG, Carvalho MJ, de Freitas D, Campos M. Nocardial keratitis following myopic keratomileusis. J Refract Surg. 1995;11(3):210-1. 
12. Perez-Santonja JJ, Sakla HF, Abad JL, Zorraquino A, Esteban J, Alio JL. Nocardial keratitis after laser in situ keratomileusis. J Refract Surg. 1997;13 (3):314-7.

13. Arff R. Episcleritis and anterior scleritis. In: Arffa RC. Grayson's diseases of the cornea. 4 th ed. St Louis, Missouri: Mosby-Year Book; 1997. p.529-44.

14. Urbano AP, Urnano AP, Torigoe AMS, Urbano I, Kara-Jose N. Esclerite infecciosa espontânea por Nocardia asteroides: Relato de caso. Arq Bras Oftalmol. 2003;66(2):223-5.
15. Colomina J, Esparza L, Buesa J, Mari J. [Corneal ulcer caused by Nocardia asteroides after penetrating keratoplasty]. Med Clin (Barc). 1997;108(11):424-5. Spanish.

16. Lee LH, Zaidman GW, Van Horn K. Topical bactrim versus trimethoprim and sulfonamide against nocardia keratitis. Cornea. 2001;20(2):179-82.

17. Gordon MA. Aerobic pathogenic Actinomycetaceae. In: Lennette EH, Ballows A, Hassler WJ, Shadomy HG, editors. Manual of clinical microbiology. $4^{\text {th }} \mathrm{ed}$. Washington, DC: American Society for Microbiology; 1985. p.249-62.

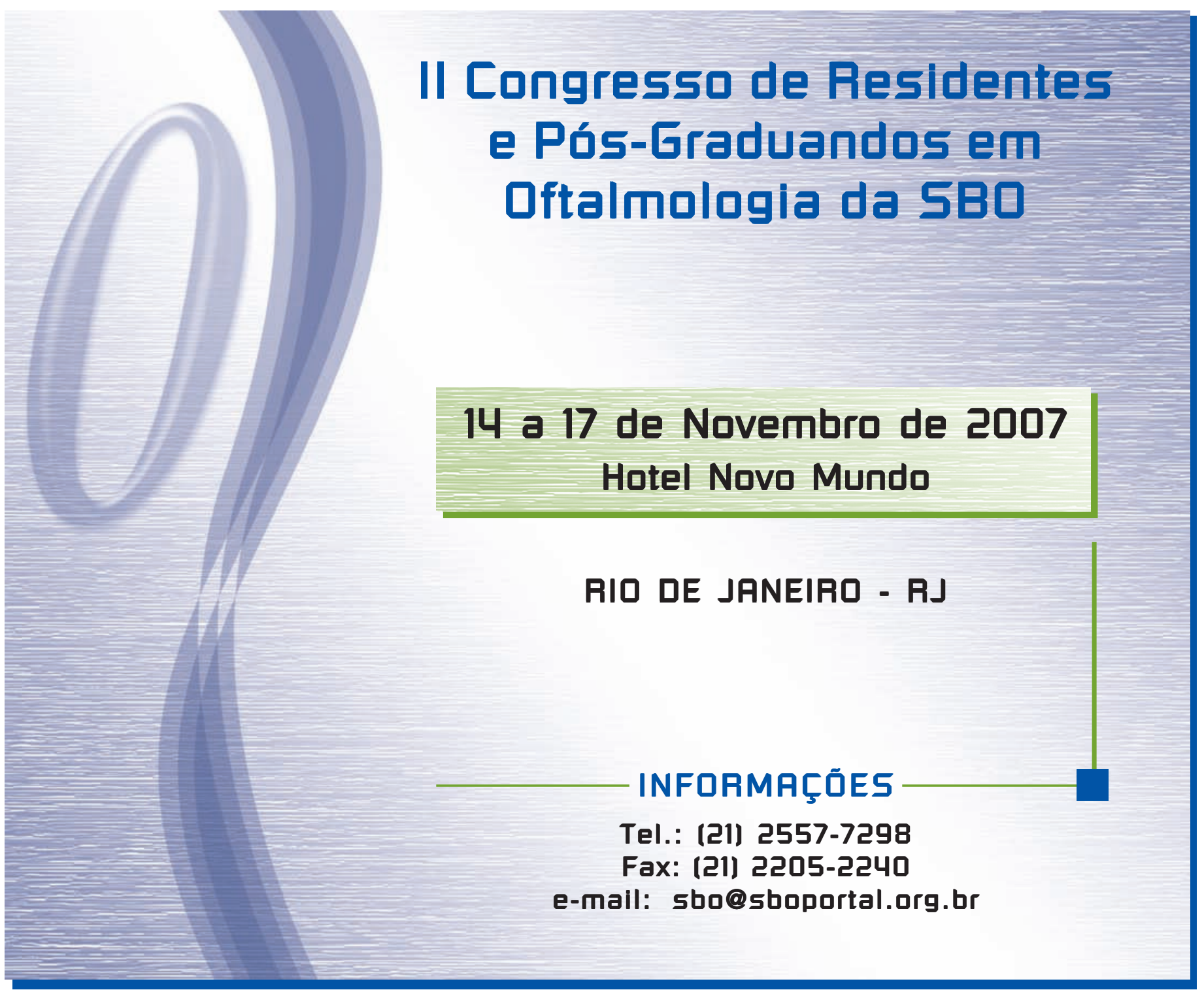

